\title{
CATATAN STUDI EVOLUSI MANAJEMEN SUMBERDAYA MANUSIA STRATEGIK
}

\author{
Majang Palupi
}

Universitas Islam Indonesia

majang_palupi@uii.ac.id

\begin{abstract}
This study is a short review and concise note of the article Lengnick-Hall et al. (2009) about his article entitled "Strategic human resource management: The evolution of the field." This study examines the evolution and chronological processes of developing strategic human resource management literature. There are seven themes in strategic human resource management. The study also discusses current and future trend issues in strategic human resource management. Finally, this paper provides a strategic human resource management research note.
\end{abstract}

Keywords : strategic human resource management

() 2017 JBTI. All rights reserved

Article history : received 15 Sep 2017; revised 17 Sep 2017; accepted 03 Okt 2017

\section{PENDAHULUAN}

Studi ini mengkaji proses evolusi dan kronologis pengembangan literatur manajemen sumber daya manusia strategik (MSDMS). Pada proses evolusinya peneliti membagi ke dalam tujuh tema yang merefleksikan arah dan kecenderungan atau tren dari para peneliti untuk penelitian yang telah dilakukan dalam kurun waktu 30 tahun. Periode yang cukup panjang ini telah membentuk bidang ini, mengembangkan konsep dasar yang mendalam, dan matang menjadi suatu domain yang memiliki pengaruh besar pada kegiatan penelitian dalam SDM dan kebijakan manajemen yang terkait. Peneliti melacak bagaimana bidang ini berkembang menjadi seperti yang ada seperti sekarang ini, dan juga mengartikulasikan temuan-temuan dan kontribusi penting, dan mendiskusikan bagaimana keyakinan kita bahwa bidang ini akan berkembang di masa mendatang. Kontribusi dari studi ini bagi bidang MSDMS adalah (1) saran tentang cara untuk mengintegrasikan penelitian yang telah ada hingga saat ini, (2) menggarisbawahi area-area di mana pertanyaan dan topik penelitian dibangun atas dasar satu sama lain, (3) menyoroti area fokus studi yang telah memperoleh cukup perhatian dan menekankan area yang belum diuji. Studi ini diharapkan dapat memberikan suatu overview yang dapat memberikan pemahaman MSDMS, baik apa yang telah dicapai maupun segala keterbatasan yang dimiliki.

Pada dasarnya Boxall, Purcell dan Wright (2007) membagi bidang MSDM ke dalam tiga sub-bidang, yaitu:

1) Manajemen Sumber Daya Manusia Mikro (MSDMM)

MSDM Mikro mencakup sub-fungsi kebijakan dan praktik SDM, dan terdiri dari dua kategori utama: (i) mengelola individu dan kelompok (seperti perekrutan, seleksi, induksi,pelatihan dan 
pengembangan, manajemen kinerja, dan remunerasi/pemberian upah), (ii) mengelola organisasi kerja dan sistem suara/pendapat karyawan, termasuk hubungan manajemen-serikat.

2) Manajemen Sumber Daya Manusia Strategik (MSDMS)

MSDM Strategik meliputi seluruh strategi SDM yang dipilih oleh unit bisnis dan perusahaan dan mengukur pengaruh strategi-strategi tersebut pada kinerja. Pada sub-bidang inilah isu-isu disain dan eksekusi diuji.

3) Manajemen Sumber Daya Manusia Internasional (MSDMI)

MSDM Internasional meliputi MSDM pada operasional perusahaan di sepanjang lintas negara.

Kaufman (2001) menyebutkan bahwa akar ilmu dari bidang MSDMS sudah ada sejak tahun 1920an di mana ahli ekonomi dan hubungan industri seperti John Commons. Para pemilik usaha (employers) memilih untuk memformulasi dan mengadopsi praktik SDM yang inovatif yang menghadirkan suatu pendekatan strategik pada pengelolaan tenaga kerja seperti penekanan pada kompetisi berdasarkan keunggulan kompetitif melalui minat yang sama, kerja sama, dan investasi pada tenaga kerja sebagai sumber daya manusia.

\section{TUJUH TEMA DALAM MSDM STRATEGIK}

\section{A. Penjelasan perspektif kontijensi dan kesesuaian}

Para ahli SDM telah memahami bahwa dalam ilmu-ilmu organisasi sekelompok praktikpraktik SDM cenderung untuk menghasilkan kinerja yang lebih baik jika praktik tersebut sesuai dengan obyektif, kondisi-kondisi dan minat-minat strategik yang spesifik, sehingga studi MSDMS awal biasanya memandang hubungan kontinjensi dan cara-cara untuk mencapai suatu kesesuaian antara aktivitas-aktivitas SDM dan hasil-hasil strategik yang diminati.

Pada tahapan awal ini peneliti menggambarkan bagaimana perhatian terhadap kesesuaian dan kontinjensi berkembang secara kronologi sepanjang tiga dekade dari awal tahun 1980an yang diawali oleh Snow dan Miles pada tahun 1984 dengan tipologi strateginya, hingga tahun 2007 di mana Richard, Murthi dan Ismail menguji dampak suatu keanekaragaman strategi SDM pada industri manufaktur versus industri berorientasi-jasa, dan lingkungan dengan sumber daya berlebih versus sumber daya terbatas.

\section{B. Perubahan dari fokus pada pengelolaan manusia menjadi penciptaan kontribusi strategic}

Pada awalnya fokus pengembangan bidang SDM adalah penjaminan bahwa karyawan memiliki kemampuan dan motivasi untuk mencapai tujuan-tujuan organisasi yang telah ditetapkan, dan terdapat cukup pekerja dengan ketrampilan khusus utuk mencapai harapan organisasi. Fokus kemudian beralih pada kontribusi modal manusia, kapabilitas strategik, dan suatu kinerja organisasi yang kompetitif. Perubahan ini merupakan tanda munculnya suatu perubahan pada peran dan pengaruh para profesional SDM dan penyesuaian kacamata yang digunakan untuk menangkap harapan-harapan yang dimiliki oleh aktivitas SDM dalam organisasi. MSDMS berargumen bahwa kontribusi-kontribusi administratif diharapkan muncul dari para profesional SDM.

Kontribusi perubahan fokus yang terjadi ini banyak dipengaruhi oleh Wright dan McMahan (1992) yang menawarkan suatu definisi MSDMS yang kemudian telah banyak diterima secara luas, yaitu "pola penyebaran aktivitas dan SDM yang terencana yang diarahkan untuk memungkinkan suatu organisasi mencapai tujuan-tujuannya." Studi ini juga mengulas enam model teoritikal MSDMS yang oleh Wright dan McMahan, yaitu: (1) perspektif perilaku, (2) model terkait 
sibernetika (cybernetic), (3) teori biaya agensi/transaksi, (4) pandangan perusahaan berbasis sumber daya, (5) model ketergantungan sumberdaya/kekuatan, (6) teori institusi.

\section{Elaborasi komponen-komponen dan struktur sistem SDM}

Tema ini menguji elemen-elemen dan struktur sistem SDM. Kebijakan-kebijakan dan praktik SDM bersifat kompleks dan merupakan proses yang saling terkait sehingga seharusnya tidak dipandang sebagai sesuatu yang berdiri sendiri, namun seharusnya diuji sebagai sub-sistem atau sebagai kesatuan. Sistem SDM merupakan kumpulan elemen yang dapat diuji dengan lebih detil dan selanjutnya menyatu menjadi konfigurasi yang unik dan aktivitas SDM dapat dipandang sebagai sistem yang terintegrasi. Schuler (1992) mengidentifikasi struktur dan komponen yang membentuk, yaitu: filosofi, kebijakan, program, praktik, dan proses.

\section{Perluasan cakupan MSDM Strategik}

Tema ini merupakan konsekuensi dari perubahan yang mengarah pada kapabilitas strategik dan kontribusi yang kompetitif sehingga tindakan yang dilakukan meluas melampaui suatu unit bisnis atau perusahaan atau suatu kelompok stakeholders. Studi ini mengulas dengan lebih detil bagaimana MSDMS di luar organisasi fokus dan pada konteks internasional. Konsekuensi dari perluasan ini maka konteks disain sistem MSDMS dan penilaian kinerja MSDMS menjadi lebih bervariasi dan rumit, tidak hanya mempertimbangkan perbedaan organisasional, namun juga perbedaan budaya dan sistem ekonomi juga harus dpertimbangkan dalam rangka pencapaian disain kebijakan dan praktik MSDMS yang efektif.

\section{E. Pencapaian implementasi dan eksekusi SDM}

Perhatian semakin meningkat terhadap kemampuan perusahaan dalam mencapai hasil strategik dan praktik SDM sesuai dengan yang diharapkan. Truss dan Gratton (1944) membedakan antara strategi bisnis yang diharapkan dan realisasi yang ada, juga antara strategi SDM yang diharapkan dan realisasi dari strategi SDM. Berbagai studi dilakukan termasuk studi pada perusahaan-perusahaan besar terkait antara yang diharapkan dengan hasil aktual terkait MSDMS, termasuk studi perbedaan persepsi tentang MSDMS di antara para manajer. Tahapan ini kemudian mendorong untuk masuk pada tema berikutnya di mana diperlukan pengujian terhadap faktor-faktor implementasi seperti halnya perlunya mengukur hasil MSDMS.

\section{F. Pengukuran hasil MSDM Strategik}

Dengan semakin pentingnya isu kinerja yang ditunjukkan dari studi-studi MSDMS, dan perhatian terhadap hasil nyata semakin meluas, maka semakin penting untuk memberikan perhatian pada usaha-usaha untuk menentukan apa yang harus diukur dan bagaimana MSDM dan kinerja organisasi dengan menelaah penggunaan harga saham dan ukuran-ukuran mendasar. Sementara Kaye (1999) melakukan studi akan pentingnya MSDMS, baik bagi individu maupun organisasi. Kaye menyarankan bahwa MSDMS mungkin dapat memperbaiki perusahaan secara mendasar, tapi mungkin juga dapat melukai karyawan, khususnya ketika karyawan dipandang sebagai suatu komoditas. Oleh karena itu Kaye menyarankan pentingnya bidang MSDMS untuk memperhatikan isu-isu terkait perspektif etika. 


\section{G. Evaluasi isu-isu metodologi}

Memasuki tahap yang semakin dewasa di mana rerangka konsep dan asumsi-asumsi teoritikal semakin matang, maka perhatian terhadap pentingnya metodologi mulai meningkat. Berbagai studi banyak dilakukan para akademisi untuk menjawab berbagai isu metodologi yang semakin meningkat pada penelitian-penelitian terkait hubungan antara sistem SDM dan kinerja organisasi. Debat diawali pada tahun 2000 yang dimulai oleh studi Gerhart, Wright, McMahan dan Snell yang memunculkan berbagai respon.

\section{TREN SAAT INI}

Periode terakhir dari studi MSDM Strategik seperti yang telah disebutkan, ditandai dengan ditetapkannya ide-ide dan isu-isu yang kemudian diuji kebenarannya, dan beberapa ide-ide atau cara baru yang menawarkan janji untuk dapat meningkatkan pengetahuan tentang bidang MSDM Strategik.

1. Adanya bukti yang menunjukkan bahwa terdapat hubungan antara sistem SDM dan kinerja organisasi meski hubungan sekuen kausal yang ada lebih bersifat timbal balik dibanding langsung. Para peneliti lebih fokus pada konstruk fokus sistem SDM dan kinerja organisasi, selain juga perspektif baru yang menuntut pandangan lebih kompleks.

2. Peneliti internasional fokus pada fenomena-fenomena MSDMS yang menarik di negara-negara berkembang dengan mempelajari kondisi-kondisi yang harus ada agar MSDMS dapat diadopsi. Bukti yang ada menunjukkan bahwa MSDMS cenderung diadopsi oleh perusahaan yang dimiliki oleh swasta atau pihak asing dibanding yang perusahaan pemerintah atau organisasi publik.

3. Lebih banyak perhatian diberikan pada topik yang terabaikan pada level stretegi SDM korporasi sehingga perlu dilakukan identifikasi konstruk seperti tingkat abstraksi dan lingkup yang ada untuk memahami aspek-aspek MSDMS. Selain itu perhatian juga perlu diberikan pada transfer praktik-praktik SDM antara induk dan anak perusahaan pada perusahaan multi nasional.

4. Para peneliti MSDMS mulai fokus pada pada isu-isu implementasi:

- Bagaimana praktik MSDMS berbeda dengan realisasi dari praktik MSDMS, sehingga apabila hanya menyandarkan pada apa yang tertulis dan tidak pada apa yang sebenarnya terjadi, berakibat mengarah pada implementasi seperti halnya hasil yang ambigu terkait hubungan antara praktik SDM dan kinerja organisasi.

- Konstruk karyawan lini depan memberikan wawasan yang lebih dalam pada proses pelaksanaan - bila karyawan tidak memahami atau tidak tahu bagaimana cara untuk berkontribusi terhadap tujuan-tujuan strategik, maka karyawan akan cenderung tidak efektif dalam melaksanakannya.

- Bila tidak terdapat persepsi yang sama tentang MSDMS antara tim manajemen puncak dan manajer senior, maka pesan yang akan disampaukan ke tingkat yang lebih rendah akan ambigu atau membingungkan.

- Perhatian juga perlu sitekankan pada implementasi merger dan akuisisi, dan pera MSDMS pada kesuksesan implementasi tersebut.

5. Peran MSDMS dalam kompetisi berbasis pengetahuan (knowledge-based) tetap terus diuji dan dieksplorasi. Para peneliti memadukan modal intelektual (modal manusia, modal sosial, dan 
modal organisasi) dengan pembelajaran organisasi untuk mengembangkan model dan kerangka kerja untuk lebih memahami bidang ini.

6. Isu-isu modal manusia (human capital) tetap terus menjadi perhatian peneliti MSDMS. Pemahaman lebih jauh tentang proses pengambilan keputusan dalam investasi modal manusia, dapat membedakan antara investasi pada personel inti dan personel pendukung, dan perolehan pemahaman yang lebih baik bagaimana keanekaragaman modal manusia mempengaruhi kinerja organisasi, semuanya berkontribusi pada pemahaman fenomena SDM yang kompleks.

\section{STUDI MSDM DARI SUDUT PANDANG BIOLOGI}

Seperti halnya proses evolusi dalam biologi, proses evolusi dalam MSDMS bukan merupakan proses yang selalu lancar. Terdapat periode di mana 'black box' yang belum terjawab oleh bidang MSDMS, meski studi telah menunjukkan bahwa kesesuaian antara strategi dan SDM saling terkait dengan kinerja yang efektif. Biologi juga menunjukkan bahwa evolusi terjadi karena perkembangan internal, perkembangan lingkungan eksternal, dan keterkaitan antara keduanya. Dalam SDM terdapat banyak faktor yang dianggap relevan dengan minat MSDMS yang kemudian memperluas cakupan isu-isu yang dieksplor, yang kemudian menginisiasi keterkaitan displin ilmu lain terhadap MSDMS, seperti manajemen strategik, manajemen internasional, manajemen pengetahuan, perilaku organisasi, dll. Suatu tema yang sebelumnya dianggap sebagai sesuatu yang independen, mulai saling terkait dengan yang lain yang menciptakan pemahaman yang mendalam akan suatu fenomena kunci. Evolusi pada MSDMS juga menunjukkan bahwa beberapa elemen menjadi lebih jelas, namun di sisi lain ada elemen yang hilang atau berkurang, yang secara keseluruhan berkontribusi terhadap MSDMS sehingga bidang ini semakin kuat dan kompleks.

Menanggapi semakin menonjolnya pandangan perusahaan berbasis sumber daya (resourcebased view) berpengaruh pada fokus SDM, tidak lagi pada apakah SDM membuat suatu perbedaan strategik, namun lebih pada bagaimana perbedaan-perbedaan dapat dikelola, ditingkatkan, dipengaruhi, dan dilestarikan. Berbagai keanekaragaman yang ada beradaptasi seperti perbedaan dari sisi geografi, orientasi strategik, publik vs. swasta, manufaktur vs. jasa, besar vs. kecil, kewirausahaan vs. kematangan, strategi berbasis aset nyata vs. strategi berbasis aset tak nyata seperti pengetahuan. Bidang MSDMS juga menekankan pemahaman akan semakin bervariasinya hasil kebijakan, praktik, keyakinan yang dimiliki SDM, yang tergambar pada aneka metoda penilaian seperti balanced scorecard, perpektif stakeholders, dan informasi kinerja pasar.

Berbagai isu, pendekatan, asumsi awal, dan paradigma membuat bidang MSDMS semakin kompleks, namun juga semakin kuat. Untuk dapat terus berkembang MSDMS harus tetap sensitif terhadap perubahan dalam lingkungan bisnis. Paradigma baru dalam bidang terkait diharapkan dapat mempengaruhi studi pada MSDMS. Pandangan berbasis sumber daya baru sekedar pondasi bagi konsep-konsep terakhir dan masih digali lebih jauh. Contohnya, apabila kumpulan "praktik terbaik" kebijakan umum dan praktik MSDMS teridentifikasi, apa yang kemudian dapat mencegah praktik tersebut ditiru oleh pesaing sehingga perusahaan kehilangan kesempatan untuk mempromosikan keunggulan kompetitif yang dimiliki.

Konsep co-evolusi menjelaskan bahwa MSDMS tidak hanya berkembang, namun MSDMS juga telah membentuk perkembangan MSDM secara umum dan kemajuan pada bidang lain yang terkait. SDM merupakan akar modal intelektual, modal sosial, dan budaya organisasi yang menerima peningkatan perhatian dan studi strategi dan teori organisasi. 


\section{AGENDA DI MASA DEPAN}

Studi Webb (1968) terkait MSDMS dari awal hingga saat penulisan studi ini lebih digambarkan sebagai coupling atau rujukan/rangkaian. Sackett \& Larson (1990) merinci di mana coupling tersebut dengan memperluas studi sebelumnya dengan (1) penggunaan subyek populasi yang berbeda, (2) menggunakan operasionalisasi satu atau lebih variabel yang berbeda, (3) memasukkan tingkat yang berbeda dari suatu variabel yang diteliti sebelumnya, (4) secara simultan menguji dua variabel yang sebelumnya hanya diuji secara independen, (5) memasukkan variabel moderator dan mediator, atau (6) memperluas studi sebelumnya dengan berbagai cara yang berbeda. Coupling bermanfaat terutama pada awal di mana domain mulai mapan, namun kontribusi marjinal berkurang ketika pemahaman dasar tercapai. Kelemahan dari studi coupling adalah potensi negatif yang muncul karena studi ini mengabaikan kelemahan yang melekat pada studi sebelumnya.

Studi-studi meyakini bahwa atensi seharusnya diberikan lebih pada isu-isu MSDM khususnya kesesuaian vertikal dan horizontal. Selain itu juga perhatian juga diberikan pada strategi pada tingkat korporasi. Sementara suatu area MSDMS yang menjanjikan adalah peningkatan modal manusia (misalnya, Hatch \& Dyer, 2004; Hitt et al., 2001; Kor \& Leblebici, 2005) yang dapat menjadi alat di mana perusahaan dapat mencapai keunggulan kompetitif (Sirmon, Hitt, \& Irlandia, 2007). Prahalad dan Hamel (1990) sebagaimana diterjemahkan ke dalam SDM oleh Dessa dan Pickens (1999) mengidentifikasi enam memanfaatkan strategi: (1) berkonsentrasi (concentrating) - memberikan titik fokus strategis bagi upaya individu, unit, dan seluruh organisasi, (2) akumulasi (accumulating) - memperpanjang dan memperluas reservoir dari suatu organisasi yaitu pengalaman dan keahlian, (3) melengkapi (complementing) - pencampuran dan menyeimbangan sumber daya yang meningkatkan nilai bersama, (4) meningkatkan (enhancing) - menambah sumber daya dengan berinvestasi pada pengembangan dan penerapan yang luas, (5) konservasi (conserving) - daur ulang, co-opting, dan melindungi sumber daya sehingga nilai mereka merupakan leverage untuk mencapai skala ekonomi, dan (6) pemulihan (recovering) - tingkat di mana dirasakan manfaatnya. Dari keenam aspek, hanya satu aspek dari peningkatan konstruk, yaitu complementing, sehingga diperlukan studi pada aspek lain.

Studi-studi juga telah dilakukan terkait MSDMS pada manajemen pengetahuan dan kompetisi berbasis pengetahuan pantas menerima perhatian dari para peneliti.

- Lengnick-Hall dan Lengnick-Hall (2003) berpendapat bahwa SDM berperan dalam perubahan terkait dengan persyaratan baru dari munculnya ekonomi pengetahuan (knowledge economy).

- Beberapa studi meneliti transfer praktik-praktik SDM di seluruh unit (misalnya, Björkman \& Lervik, 2007).

- Teori juga muncul tentang bagaimana MSDMS memainkan peran dalam isu yang lebih besar dari penciptaan dan penyimpanan pengetahuan, dan diseminasi dalam organisasi (misalnya, Kang et al., 2007).

- Kogut dan Zander (1996) berpendapat bahwa sebuah organisasi yang kuat maka identitas berperan dalam mencapai koordinasi dan pembelajaran. Peran SDM dalam mengembangkan dan melembagakan suatu identitas organisasi adalah sarana penting antara MSDMS dan keunggulan kompetitif potensial melalui pengetahuan.

- Collins dan Smith (2006) menunjukkan bahwa praktek-praktek SDM mempengaruhi iklim sosial organisasi, yang pada gilirannya, kombinasi dan bentuk pertukaran pengetahuan mengarah pada kinerja organisasi yang lebih baik.

- Minbaeva et al. (2003) memandang hubungan antara praktek-praktek SDM dan kapasitas daya serap, dan menemukan bahwa daya serap memfasilitasi transfer pengetahuan antara perusahaan multinasional. 
Salah satu manfaat MSDMS bagi penelitian adalah pertemuan antara keuntungan berbasis pengetahuan dan sistem SDM.

- Pembahasan penerapan MSDMS pada rantai pasokan (supply chain) seperti yang telah dibahas oleh Schuler dan MacMillan (1984) dan peran dari stakeholder eksternal seperti yang pernah ditulis oleh Way dan Johnson (2005). Melihat apakah organisasi-organisasi dalam rantai pasokan mengkoordinasikan kegiatan SDM dengan cara yang menguntungkan seluruh "ekosistem", dan apakah rantai pasokan yang memiliki fokus pada MSDMS memperoleh keuntungan kompetitif atas rantai pasokan yang memiliki yang memiliki sedikit atau tidak ada koordinasi antar kegiatan SDM dalam organisasi? Ataukah sebaliknya apakah praktik-praktik SHRM mencerminkan suatu orientasi rantai pasokan seperti ditulis oleh Min, Mentzer \& Ladd (2007) dan memungkinkan sebuah perusahaan untuk mendapatkan keuntungan kompetitif dari yang lainnya dalam rantai nilai tersebut?

- Sementara isu penting lain yang diangkat dalam penelitian sebelumnya (Kaye, 1999) namun belum menerima perhatian yang cukup menyangkut implikasi etika dari SHRM. Elemen "manusia (human)" belum mendapat perhatian seperti halnya elemen berbasis sumber-daya yang lebih menekankan pada strategik dan faktor-faktor sumber-daya pada aktifitas-aktifitas MSDMS: pengaruh diversifikasi praktik SDM untuk kelompok, pengaruh kelelahan terkait dengan suatu fokus pada pembelajaran berkelanjutan, pandangan karyawan sebagai sumberdaya yang perlu ditingkatkan dibanding dipelihara.

- Mengembangkan teori multi-level yang tepat untuk meneliti isu-isu MSDMS yang semakin kompleks di dalam organisasi yang mengarah pada pengaruhnya dalam kinerja organisasi.

- Ostroff dan Bowen (2000) menawarkan model menarik yang belum diuji.

- Ployhart dan koleganya telah menunjukkan bagaimana strategi kepegawaian diuji dari berbagai level.

\section{CATATAN PENELITIAN MSDM STRATEGIK}

Selanjutnya beberapa catatan ringkas terkait dengan penelitian MSDMS ini adalah:

1. Pentingnya penelitian MSDMS dan kinerja dengan menggunakan tidak hanya perspektif yang bersifat universalistik, namun juga kontinjensi (Tjahjono, 2005) dan konfigurasional (Delery \& Doty, 1996).

2. Pentingnya pengembangan penelitian yang tidak bersifat straight jacket dengan pengembangan penelitian MSDMS yang bersifat eksploratif.

3. Mengakomodasi pendekatan penelitian yang bersifat induktif di bidang MSDMS seperti studi kasus, terutama untuk mengikuti perkembangan kasus-kasus SDM dalam bisnis.

4. Melihat pada perspektif emic di mana terdapat sejumlah kasus kompensasi dalam organisasi yang bersandarkan pada kepercayaan dan relijiusitas di sejumlah organisasi modern pendidikan Islam. Pendekatan etnografi menjadi menarik untuk mengungkap fenomena emic di setiap konteks penelitian.

\section{DAFTAR PUSTAKA}

Baird, L., \& Meshoulam, I., 1988, Managing two fits of strategic human resource management. Academy of Management Review, 13(1), 116-128. 
Barney, J. B., 1986, Organization culture: Can it be a source of sustained competitive advantage? Academy of Management Review, 11(3), 656-665.

Barney, J. B., \&Wright, P. M., 1998, On becoming a strategic partner: The role of human resources in gaining competitive advantage. Human Resource Management, 37(1), 31-46.

Becker, B. E., \& Huselid, M. A., 1999, Overview: Strategic human resource management in five leading firms. Human Resource Management, 38(4), 287-301.

Becker, B. E., \& Huselid, M. A., 2006, Strategic human resources management: Where do we go from here? Journal of Management, 32(6), 898-925.

Björkman, I., \& Lervik, J. E., 2007, Transferring HR practices within multinational corporations. Human Resource Management Journal, 17(4), 320-335.

Boxall, P., Purcell, J., \& Wright, P. M., 2007, Human resource management: Scope, analysis and significance. In P. Boxall, J. Purcell, \& P. M. Wright (Eds.), The handbook of human resource management (pp. 1-16). Oxford: Oxford University Press.

Collins, C. J., \& Smith, K. G., 2006, Knowledge exchange and combination: The role of human resource practices in the performance of high-technology firms. Academy of Management Journal, 49(3), 544-560.

Collis, D. J., \& Rukstad, M. G., 2008, Can you say what your strategy is? Harvard Business Review, 86, 82-90.

Delery, J. E., \& Doty, D. H., 1996, Modes of theorizing in strategic human resource management: Tests of universalistic, contingency. Academy of ManagementJournal, 39(4), 802-835.

Dess, G. G., \& Pickens, J. C., 1999, Beyond productivity: How leading companies achieve superior performance by leveraging their human capital. New York: American Management Association.

Gerhart, B., Wright, P. M., \& McMahan, G. C., 2000, Measurement error in research on the human resources and firm performance relationship: Further evidenceand analysis. Personnel Psychology, 53(4), 855-872.

Gerhart, B.,Wright, P. M., McMahan, G. C., \& Snell, S. A., 2000, Measurement error in research on human resources and firm performance: How much error is there and how does it influence effect size estimates? Personnel Psychology, 53(4), 803-834.

Hatch, N. W., \& Dyer, J. H., 2004, Human capital and learning as a source of sustainable competitive advantage. Strategic Management Journal, 25(12), 1155-1178.

Hitt, M. A., Bierman, L., Shimizu, K., \& Kochhar, R., 2001, Direct and moderating effects of human capital on strategy and performance in professional service firms:A resource-based perspective. Academy of Management Journal, 44(1), 13-28.

Huselid, M. A., Jackson, S. E., \& Schuler, R. S., 1997, Technical and strategic human resources management effectiveness as determinants of firm performance. Academy of Management Journal, 40(1), 171-188.

Kang, S. C., Morris, S. S., \& Snell, S. A., 2007, Relational archetypes, organizational learning, and value creation: Extending the human resource architecture. Academy of Management Review, 32(1), 236-256.

Kaufman, B., 2001, The theory and practice of strategic HRM and participative management. Human Resource Management Review, 11(4), 505-533.

Kaye, L., 1999, Strategic human resources management in Australia: The human cost. International Journal of Manpower, 20(8), 577-587. 
Kogut, B., \& Zander, U., 1996, What firms do? Coordination, identity, and learning. Organization Science, 7(5), 502-518.

Lengnick-Hall, C. A., \& Lengnick-Hall, M. L., 1988, Strategic human resources management: A review of the literature and a proposed typology. Academy of Management Review, 13(3), 454-470.

Lengnick-Hall, M. L., \& Lengnick-Hall, C. A., 2003, Human resource management in the knowledge economy: New challenges, new roles, new capabilities. San Francisco, CA: Berrett-Koehler.

Lepak, D. P., Taylor, M. S., Tekleab, A. G., Marrone, J. A., \& Cohen, D. J., 2007, An examination of the use of high-investment human resource systems for core and support employees. Human Resource Management, 46(2), 223-246.

Miles, R. E., \& Snow, C. C., 1984, Designing strategic human resources systems. Organizational Dynamics, 13(1), 36-52.

Milliman, J., Von Glinow, M. A., \& Nathan, M., 1991, Organizational life cycles and strategic international human resource management in multinationalcompanies: Implications for congruence theory. Academy of Management Review, 16(2), 318-339.

Min, S., Mentzer, J. T., \& Ladd, R. T., 2007, A market orientation in supply chain management. Journal of the Academy of Marketing Sciences, 35, 507-522.

Minbaeva, D., Pedersen, T., Björkman, I., Fey, C. F., \& Perk, H. J., 2003, MNC knowledge transfer, subsidiary absorptive capacity, and HRM. International Business Studies, 34(6), 586-599.

Nahapiet, J., \& Ghoshal, S., 1998, Social capital, intellectual capital, and the organizational advantage. Academy of Management Review, 23(2), 242-266.

Ostroff, C., \& Bowen, D. E., 2000, Moving HR to a higher level: HR practices and organizational effectiveness. In K. Klein \& S.W. J. Kozlowski (Eds.), Multilevel theory, research, and methods in organizations: Foundations, extensions, and new directions (pp. 221-266). San Francisco: Jossey-Bass.

Porter, M. E.,1985, Competitive advantage. New York: Free Press.

Prahalad, C. K., \& Hamel, G., 1990, Strategy as stretch and leverage. Harvard Business Review, 71, 75-84.

Sackett, P. R., \& Larson, J. R., 1990, Research strategies and tactics in industrial and organizational psychology. In M. D. Dunnette \& L. M. Hough (Eds.), Handbook of industrial and organizational psychology (pp. 419-489). Palo Alto, CA: Consulting Psychologists Press.

Schuler, R. S., 1992, Strategic human resources management: Linking the people with the strategic needs of the business. Organizational Dynamics, 21(1), 18-32.

Schuler, R. S., \& Jackson, S. E., 1987, Linking competitive strategies with human resource management practices. Academy of Management Executive, 1(3), 207-219.

Schuler, R. S., \& MacMillan, I. C., 1984, Gaining competitive advantage through human resource management practices. Human Resource Management, 23(2),241-256.

Sirmon, D. G., Hitt, M. A., \& Ireland, R. D., 2007, Managing firm resources in dynamic environments to create value: Looking inside the black box. Academy of Management Review, 32, 273-292.

Truss, C., \& Gratton, L., 1994, Strategic human resource management: A conceptual approach. International Journal of Human Resource Management, 5(3), 663-686. 
Tjahjono, H.K., 2005, Praktik-praktik manajemen SDM strategik; pengujian universalistik dan kontijensi dalam menjelaskan kinerja organisasional. Jurnal Bisnis dan Ekonomi Kinerja, 9(2) 123-134.

Way, S. A., \& Johnson, D. E., 2005, Theorizing about the impact of strategic human resource management. Human Resource Management Review, 15(1), 1-19.

Webb, W. B., 1968, A “couple” of experiments. American Psychologist, 23, 428-433.

Wright, P. M., Gardner, T., Moynihan, L., Park, H., Gerhart, B., \& Delery, J., 2001, Measurement error in research on human resources and firm performance:Additional data and suggestions for future research. Personnel Psychology, 54(4), 875-902.

Wright, P. M., \& McMahan, G., 1992, Theoretical perspectives for strategic human resource management. Journal of Management, 18(2), 295-320.

Wright, P., Snell, S., \& Dyer, L., 2005, New models of strategic HRM in a global context. International Journal of Human Resource Management, 16(6), 875-881. 